\title{
PENENTUAN KEDALAMAN SUMUR BOR BERDASARKAN DATA GEOLISTRIK RESISTIVITAS DI BEBERAPA KAMPUNG DI KABUPATEN FAK-FAK
}

\author{
Khristian Enggar Pamuji \\ Prodi Fisika Jurusan Fisika FMIPA UNIPA \\ Jl. Gunung salju Amban, Manokwari \\ e-mail : k_enggar_p@yahoo.com
}

\begin{abstract}
Geoelectrical Resistivity method is a geophysical method that can be used to determine subsurface geology based on rock resistivity image. Resistivity survey has been done in some villages, in Fak Fak Regency, West Papua Province. The measurement method that used is sounding, whereas electrode configuration used is Dipole-dipole configuration with a stretch of $100-150 \mathrm{~m}$. The data obtained are then processed by Progress Res2Dinv. The results of this survey obtained show that in the resistivity sounding measurement point found any good groundwater aquifers, as the water source of drilled well. Water layer with the thickness between 1-3 $\mathrm{m}$ at the surface (alluvial) is a rain water infiltration that is not recommended to make boreholes at this point.
\end{abstract}

Keyword: Resistivity, groundwater aquife, borehole

\section{PENDAHULUAN}

Air adalah urat nadi dan jantung bagi Pangan dan air adalah dua kebutuhan dasar manusia. Namun kondisi global pada tahun 2002 mengindikasikan bahwa dari sepuluh orang, lima diantaranya memiliki akses ke suplai air berpipa di rumah, tiga orang memiliki tipe suplai air lainnya seperti mata air terlindung atau pipa air publik, dua orang tidak sama sekali. Dan sebagai tambahan, empat dari sepuluh orang tersebut hidup tanpa sanitasi yang berarti (Earth Summit 2002).

Diperkirakan $15 \%$ penggunaan air di seluruh dunia adalah di rumah tangga. Hal ini meliputi air minum, mandi, memasak, sanitasi, dan berkebun. Kebutuhan minimum air yang dibutuhkan dalam rumah tangga menurut perkiraan adalah sekitar 50 liter per individu per hari, belum termasuk kebutuhan berkebun. Air minum haruslah air yang berkualitas tinggi sehingga dapat langsung dikonsumsi tanpa risiko bahaya.
Masyarakat di kabupaten Fak-Fak, Papua Barat pada umumnya memanfaatkan air tanah untuk keperluan domestik. Dilihat dari sumbernya, potensi air tanah dari segi kuantitas di daerah ini diperkirakan cukup. Masalahnya adalah distribusi air tersebut tidak merata di setiap tempat, seperti yang terjadi di Kampung Bahamdandara, Kampung Woos, kampung Waremu dan Kampung Bisa. Bentang alam dan kondisi fisik yang ada mempengaruhi distribusi air tersebut. Tujuan dari survei geolistrik resistivitas ini adalah untuk mengetahui keberadaan lapisan air tanah sebelum dilakukan pembuatan sumur bor. Kondisi air tanah dapat diketahui dari kondisi akuifer. Akuifer merupakan suatu lapisan batuan atau formasi geologi yang mempunyai struktur yang memungkinkan air untuk masuk dan bergerak melaluinya dalam kondisi normal. Dengan mengetahui kondisi air tanah, maka kita dapat memperkirakan kedalaman lubang bor (sumur bor) yang paling efektif. 


\section{TINJAUAN PUSTAKA}

Tahanan jenis adalah suatu sifat dasar material, yang mana mencirikan material tersebut, seperti halnya berat jenis. Pengukuran tahanan jenis dilapangan pada material seperti mineral sulfida, lempung, pasir, bemacammacam tipe batuan sedimen lainnya, batuan metamorf dan batuan beku, yang akan menghasilkan suatu kesimpulan untuk membedakan satu tipe dari yang lainnya tanpa melakukan penggalian.

Penggunaan dilapangan berdasarkan atas kemampuan alat untuk menghantarkan arus listrik kedalam material yang mempunyai kemampuan yang berbeda dalam menghantarkan arus listrik pada berbagai kedalaman yang diketahui dan untuk mengukur tahanan jenis pada kedalaman tersebut.

\section{Metode Resistivity}

Metode Geolistrik Resistivitas memanfaatkan sifat penjalaran arus listrik yang diinjeksikan ke dalam tanah melalui dua buah elektroda "elektroda arus". Dengan adanya aliran arus listrik tersebut maka akan menimbulkan tegangan listrik di dalam tanah. Tegangan listrik yang terjadi di permukaan tanah diukur dengan menggunakan multimeter yang terhubung melalui 2 buah 'Elektroda Tegangan' . Bila Arus Listrik yang masuk melalui elektroda Arus diubah menjadi lebih besar, maka tegangan listrik yang terjadi pada elektroda Tegangan ikut berubah sesuai dengan daya hantar arus listrik pada batuan yang terinjeksi tersebut. Respon beda potensial yang terjadi antara dua buah elektroda inilah yang digunakan untuk menggambarkan keadaan bawah permukaan [1][3].

Metode resistivitas telah terbukti berhasil dalam kegiatan eksplorasi dangkal, seperti eksplorasi air tanah (penentuan aquifer), analisa struktur lapisan tanah untuk tujuan geoteknik, dan pencairan mineral logam [3].

\section{Konfigurasi dipole-dipole}

Konfigurasi Dipole-dipole ini banyak digunakan dalam survey resistivity atau IP karena memiliki efek kopling yang rendah antara sirkuit arus dan sirkuit potensial. Dengan
P1 dan P2 adalah pasangan elektroda potensial, $\mathrm{C} 1$ dan $\mathrm{C} 2$ adalah pasangan elektroda arus dengan jarak a yang berbeda-beda. Faktor geometris dalam konfigurasi dipole-dipole persamaannya adalah :

$$
\begin{gathered}
K=n(n+1)(n+2) \pi a \\
\rho_{s}=n(n+1)(n+2) \pi a \frac{\Delta V}{I} \\
\text { dengan } \rho_{s} \quad: \text { resistivitas semu }(\mathrm{Ohm} . \mathrm{m}), \\
\Delta V \quad: \text { beda potensial }(V), \\
\mathrm{I} \quad: \text { arus yang diinjeksikan }(\mathrm{A}), \\
\mathrm{a} \quad: \text { spasi antara pasangan } \\
\text { elektroda arus dan elektroda } \\
\text { potensial }(\mathrm{m}) .
\end{gathered}
$$

\section{METODE}

\subsection{Akuisisi Data}

\section{Alat yang digunakan}

Alat merupakan hal yang sangat penting karena berhubungan langsung dengan kualitas dan kuantitas data. Dalam survei ini alat yang digunakan meliputi :
a. 1 Unit Resisitivitimeter Naniura
b. 4 roll kabel
c. 4 buah elektroda
d. 1 buah accu 12 volt.

\section{Metode pengukuran}

Metode pengukuran resistivity yang digunakan pada survey ini adalah metode Vertical electrical sounding. Metode ini digunakan untuk mengetahui perubahan tahanan jenis secara vertical atau untuk mengetahui perlapisan tanah/batuan dibawah permukaan. Sedangkan konfigurasi elektroda yang digunakan adalah dengan menggunakan konfigurasi Dipole-dipole dengan bentangan 100 $-150 \mathrm{~m}$. Lokasi titik-titik pengambilan data berada di lima kampung .

\subsection{Pengolahan Data}

Pengolahan data resistivitas pada survei ini menggunakan perangkat lunak Res2Dinv. Res2Dinv adalah sebuah program komputer yang secara otomatis menentukan model resestivity $2 \mathrm{D}$ untuk bawah permukaan dari data 
hasil survey. Model 2D menggunakan program inversi, yang terdiri dari sejumlah kotak persegi.

\subsection{Interpretasi}

Langkah terakhir ini sering disebut sebagai suatu langkah penerjemahan bahasa fisis (resisitivitas) menjadi bahasa geologi. Oleh karena itu didalam analisa interpretasi ini sangat diperlukan pengetahuan geologi, baik struktur maupun proses sedimentasi untuk mengetahui perkiraan jenis-jenis batuan yang berada dibawah lintasan survei.

\subsection{Kampung Bahamdandara}

Lokasi survei terletak di antara $2^{\circ} 49^{\prime} 57.64^{\prime \prime} \mathrm{S}$ $2^{\circ} 50^{\prime} 03.12^{\prime \prime} \mathrm{S}$ dan $132^{\circ} 41^{\prime} 22.76^{\prime \prime} \mathrm{E}-132^{\circ} 41^{\prime}$ 26.48" E, berada di Kampung Bahamdandara, Distrik Bahamdandara, Kabupaten Fak-Fak. Lokasi ini berada pada ketinggian $\pm 18 \mathrm{~m}$ diatas permukaan air laut dan berjarak $\pm 5 \mathrm{Km}$ dari garis pantai. Panjang bentangan $200 \mathrm{~m}$, dengan spasi elektroda $25 \mathrm{~m}$ dan arah lintasan relatif Barat Laut - Tenggara $\left(\mathrm{N} 135^{\circ} \mathrm{E}\right)$.

\section{HASIL DAN PEMBAHASAN}

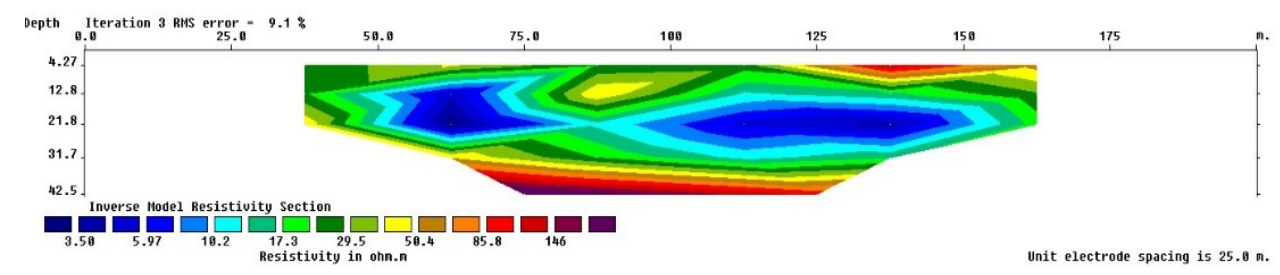

\section{Gambar 1. Hasil pengolahan data resistivity dengan menggunakan Res2Dinv di Kampung Bahamdandara, Distrik Bahamdandara, Kabupaten Fak-Fak.}

Hasil yang diperoleh dari pengolahan data dengan mengunakan sofware Res2Dinv dapat diklasifikasikan menjadi beberapa lapisan isoresistivity (batuan dengan tahanan jenis sama) dengan kesalahan RMS $9.1 \%$, seperti terlihat pada Gambar 1. Nilai tahanan jenis kearah lateral/horisontal mengalami variasi/perbedaan yang tidak terlalu signifikan. Pada kedalaman 0 $-30 \mathrm{~m}$, nilai tahanan jenis secara lateral bervariasi antara $3-150 \Omega$. Nilai tahanan jenis didominasi warna hijau dan biru yang memiliki nilai tahanan jenis berkisar antara $3 \Omega \mathrm{m}$ (warna biru) sampai $50 \Omega \mathrm{m}$ (Warna kuning). Sedangkan pada kedalaman di bawah $30 \mathrm{~m}$ lebih didominasi tahanan jenis antara $50-150 \Omega \mathrm{m}$ (warna cokelat). Nilai tanahan jenis yang tinggi (150 $\Omega \mathrm{m})$ ini berasosiasi dengan batuan gamping yang berada di lokasi survei, sedangkan warna biru atau nilai tahanan jenis rendah $(<10 \Omega \mathrm{m})$ beasosiasi dengan lapisan batuan yang memiliki kadar air tinggi.

Pada arah vertikal, nilai tahanan jenis mengalami variasi/perbedaan. Pada bagian atas (kedalaman 0-10 m) nilai tahanan jenis diatas berkisar antara $15-30 \Omega \mathrm{m}$. Lapisan ini diduga merupakan lapisan aluvial yang mengandung sedikit mengandung air. Nilai Resistivitas menurun hingga dibawah $10 \Omega \mathrm{m}$, dengan nilai terendah mencapai $3 \Omega \mathrm{m}$. Resistivitas dengan nilai tersebut dijumpai di kedalaman $25 \mathrm{~m}$ (warna Biru tua). Diduga keberadaan akuifer berada pada lapisan di kedalaman ini (Kedalaman $10-30 \mathrm{~m}$ ), seperti yang terlihat pada gambar 2.

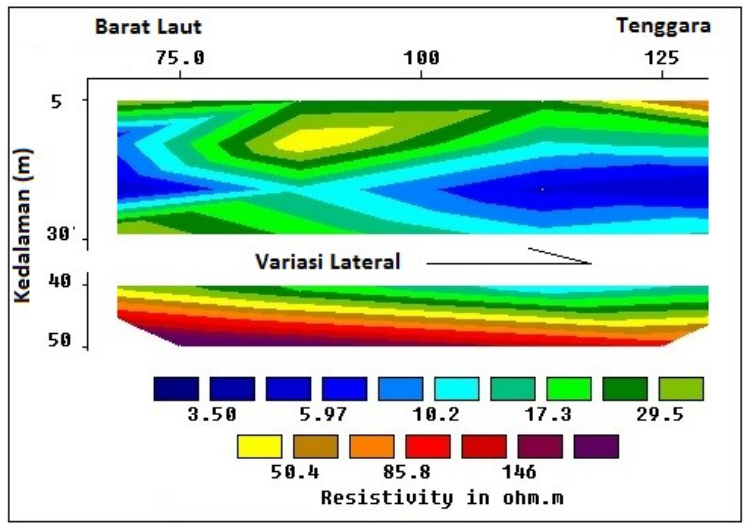

Gambar 2. Variasi Lateral di lintasan 1 
Di bagian bawah, mulai kedalaman kedalaman sekitar $35 \mathrm{~m}$, nilai resistivitas kembali menunjukan peningkatan (Warna kuning Cokelat tua). Dilihat dari kecenderungannya, hingga kedalaman dibawah $50 \mathrm{~m}$, tidak dijumpai nilai resistivitas yang lebih rendah. Diperkirakan nilai resistivitas terus meningkat sehingga diperkirakan tidak dijumpai lagi adanya akuifer air tanah (gambar 3).

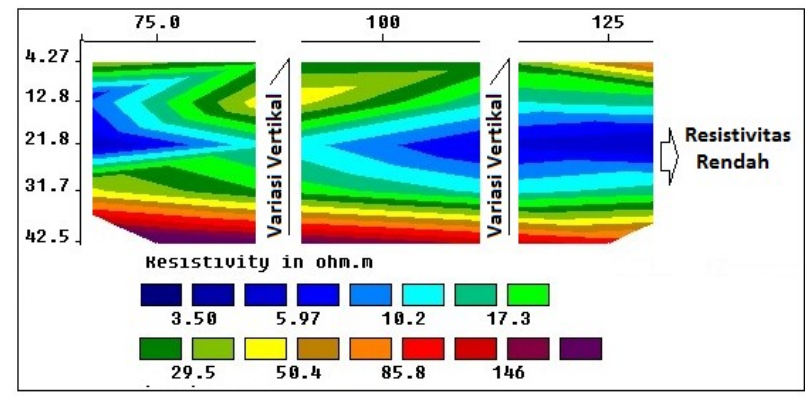

\section{Gambar 3. Variasi vertikal di lintasan 1}

Dari beberapa lapisan isoresistivity tersebut terlihat bahwa lapisan yang banyak mengandung air tanah berada pada kedalaman $15-30 \mathrm{~m}$. Sumur bor dapat dibuat di lokasi ini $(62 \mathrm{~m}$ dari titik awal) dengan kedalaman hingga $40 \mathrm{~m}$ (Koordinat $2^{\circ} 49^{\prime} 59.77^{\prime \prime} \mathrm{S}$ dan $132^{\circ} 41^{\prime} 23.33^{\prime \prime}$ $\mathrm{E}$ dan air diperkirakan dijumpai mulia kedalaman $12 \mathrm{~m}$. Sumur bor juga dapat dibuat di jarak $138 \mathrm{~m}$ dari titik awal dengan kedalaman hingga $40 \mathrm{~m}$ (Koordinat $2^{\circ} 50^{\prime} 01.90^{\prime \prime} \mathrm{S}$ dan $132^{\circ} 41^{\prime} 25.20^{\prime \prime}$ E). Lokasi ini dapat dijadikan alternatif dan air diperkirakan dijumpai mulia kedalaman 16 m (Gambar 4).

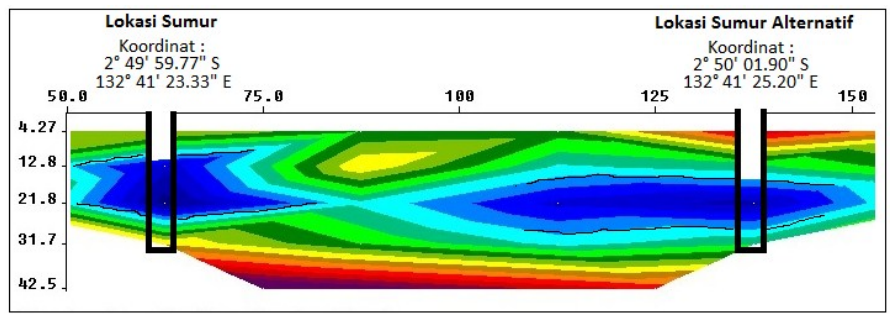

Gambar 4. Lokasi Rekomendasi Sumur Bor

\subsection{Kampung Woos}

Lokasi survei terletak di antara $2^{\circ} 54^{\prime} 22.70^{\prime \prime S}$ $00^{\circ} 54^{\prime} 18.20^{\prime \prime} \mathrm{S}$ dan $132^{\circ} 44^{\prime} 43.26^{\prime \prime} \mathrm{E}-132^{\circ}$ 44' 46.16" E, berada di Kampung Woos, Distrik Bahamdandara, Kabupaten Fak-Fak. Lokasi ini berada pada ketinggian \pm 20 m diatas permukaan air laut dan berjarak $\pm 11.5 \mathrm{Km}$ dari garis pantai. Panjang bentangan $160 \mathrm{~m}$, dengan spasi elektroda $20 \mathrm{~m}$ dan arah lintasan relatif Barat daya - timur laut $\left(\mathrm{N} 215^{\circ} \mathrm{E}\right)$. Hasil yang diperoleh dari pengolahan data dengan mengunakan sofware Res2Dinv dapat diklasifikasikan menjadi beberapa lapisan isoresistivity (batuan dengan tahanan jenis sama) dengan kesalahan RMS 9.1\%, seperti terlihat pada Gambar

5.

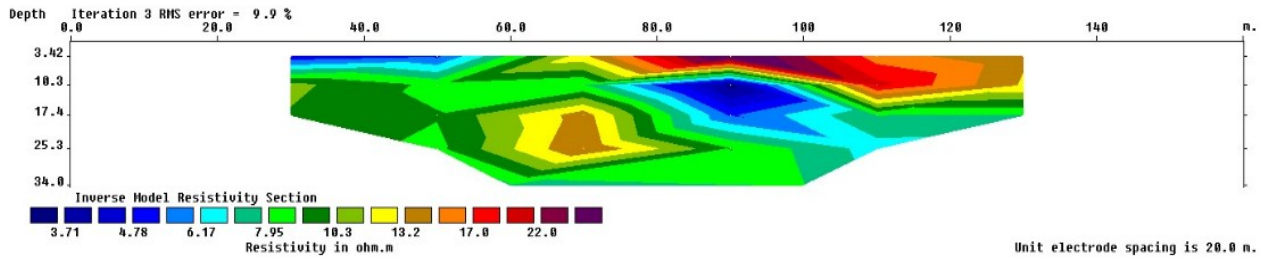

Gambar 5. Hasil pengolahan data resistivity dengan menggunakan Res2Dinv di Kampung Woos, Distrik Bahamdandara, Kabupaten Fak-Fak.

Nilai tahanan jenis kearah lateral/horisontal tidak mengalami variasi/perbedaan yang signifikan. Nilai tahanan jenis pada kedalaman 0 - 15 berkisar antara 3 - $30 \Omega \mathrm{m}$, sedangkan pada kedalaman 15 - 30 m nilai tahanan jenis antara 3 - $15 \Omega \mathrm{m}$ Gambar 8.

Nilai tanahan jenis yang lebih tinggi berada di bagian barat daya, sedangkan nilai tahanan jensi paling rendah berada di bagian bagian timur laut. 


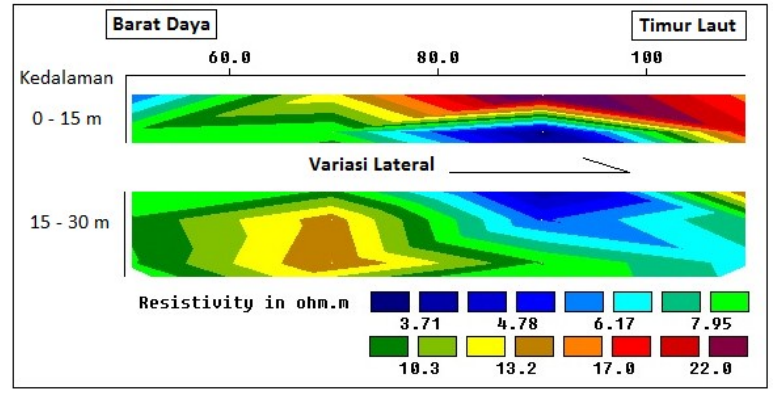

Gambar 6. Variasi Lateral Lintasan 2

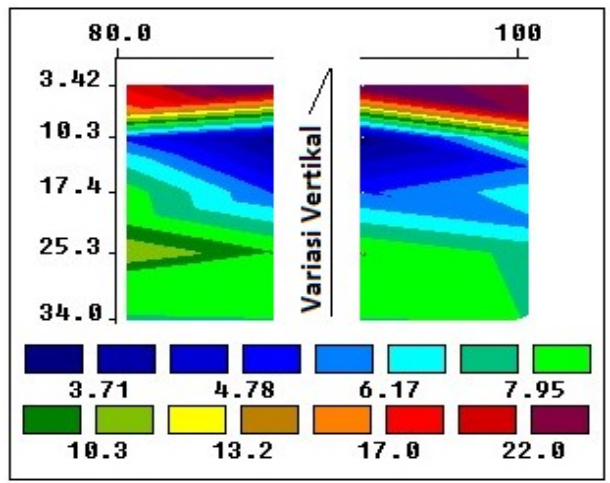

Gambar 7. Variasi vertikal di lintasan 2

Pada arah vertikal (Gambar 7), nilai tahanan jenis mengalami variasi/perbedaan terutama pada jarak $80-100 \mathrm{~m}$ ar titik awal. Pada bagian atas (kedalaman 0-8 m) nilai tahanan jenis diatas $15 \Omega \mathrm{m}$ (warna cokelat). Lapisan ini diduga merupakan lapisan batuan yang kering atau sedikit mengandung air, diduga lapisan ini merupakan aluvial. Resistivitas mengalami penurunan sampai dibawah $10 \Omega \mathrm{m}$ pada kedalaman 8 -25 m. Pada kedalaman inilah keberadaan akuifer air tanah diduga berada. Pada kedalaman di bawah $25 \mathrm{~m}$, nilai resisivitas cenderungan meningkat dan terus meningkat sampai kedalaman dibawah $40 \mathrm{~m}$.

Dari beberapa lapisan isoresistivity tersebut terlihat bahwa lapisan yang banyak mengandung air tanah berada pada kedalaman $8-25 \mathrm{~m}$ dan berjarak $90 \mathrm{~m}$ dari titik awal. Sumur bor dapat dibuat di lokasi ini dengan kedalaman hingga 40 m (Koordinat $2^{\circ} 54^{\prime} 19.84^{\prime \prime} \mathrm{S}$ dan $132^{\circ} 44^{\prime}$ 46.01" Edan air diperkirakan dijumpai mulia kedalaman $8 \mathrm{~m}$ (Gambar 8).

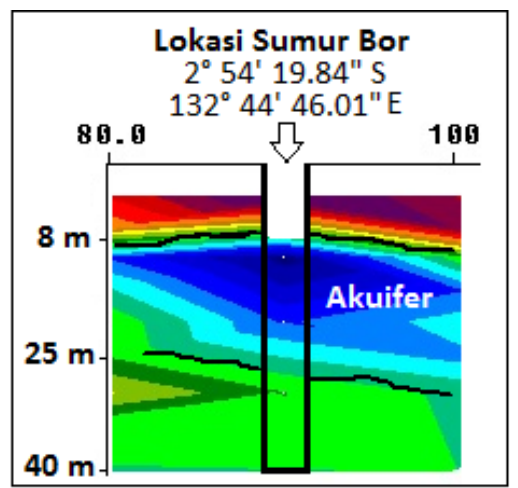

\section{Gambar 8. Lokasi Rekomendasi Sumur Bor di Kampung Woos}

\subsection{Kampung Waremu}

Lokasi survei terletak di antara $2^{\circ} 55^{\prime} 31.64 " \mathrm{~S}$ $00^{\circ} 55^{\prime} 37.50^{\prime \prime} \mathrm{S}$ dan $132^{\circ} 45^{\prime} 54.69^{\prime \prime} \mathrm{E}-132^{\circ}$ 45' 57.66" E, berada di Kampung Waremu, Distrik Bahamdandara, Kabupaten Fak-Fak. Lokasi ini berada pada ketinggian $\pm 18 \mathrm{~m}$ diatas permukaan air laut dan berjarak $\pm 14 \mathrm{Km}$ dari garis pantai. Panjang bentangan $200 \mathrm{~m}$, dengan spasi elektroda $25 \mathrm{~m}$ dan arah lintasan relatif Barat Laut - Tenggara (N $150^{\circ}$ E. Hasil yang diperoleh dari pengolahan data dengan mengunakan sofware Res2Dinv dapat diklasifikasikan menjadi beberapa lapisan isoresistivity (batuan dengan tahanan jenis sama) dengan kesalahan RMS $5.8 \%$, seperti terlihat pada Gambar

9.

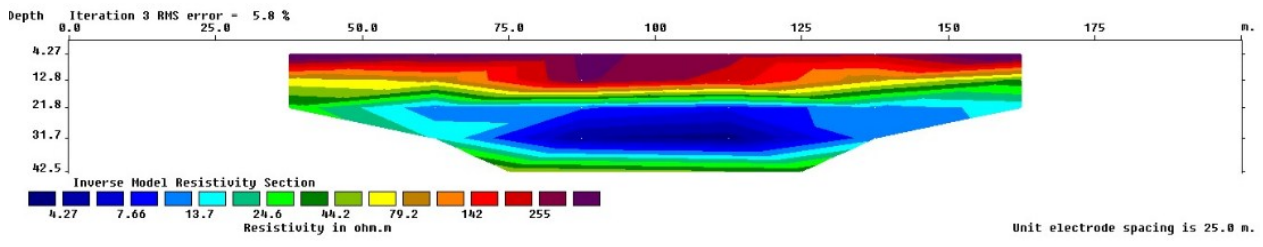

Gambar 9. Hasil pengolahan data resistivity dengan menggunakan Res2Dinv di Kampung Waremu, Distrik Bahamdandara, Kabupaten Fak-Fak. 
Nilai tahanan jenis kearah lateral/horisontal tidak mengalami variasi/perbedaan yang signifikan. Nilai tanahan jenis yang lebih tinggi berada di bagian atas (Warna Cokelat), sedangkan nilai tahanan jenis paling rendah berada di bagian bagian timur laut. Nilai tahanan jenis pada kedalaman $0-20$ berkisar antara $50-255 \Omega \mathrm{m}$, sedangkan pada kedalaman $20-42 \mathrm{~m}$ didominasi oleh nilai tahanan jenis yang rendah, yakni antara $4-20$ $\Omega \mathrm{m}$ Gambar 10 .

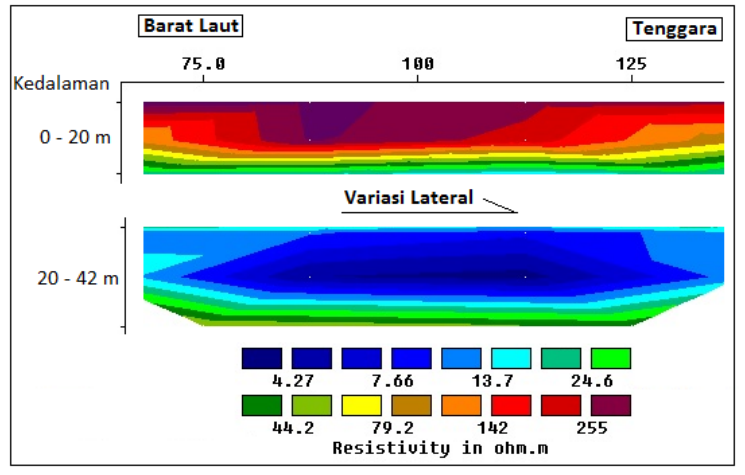

Gambar 10. Variasi Lateral Lintasan 3

Pada arah vertikal, nilai tahanan jenis mengalami variasi/perbedaan terutama pada jarak $60-130 \mathrm{~m}$ ar titik awal. Pada bagian atas (kedalaman 0-12 m) nilai tahanan jenis diatas $100 \Omega \mathrm{m}$ (warna cokelat). Lapisan ini diduga merupakan lapisan batuan yang kering atau sedikit mengandung air, diduga lapisan ini merupakan aluvial. Resistivitas mengalami penurunan menjadi 4 - $12 \Omega \mathrm{m}$ pada kedalaman 21 - $35 \mathrm{~m}$. Pada kedalaman inilah keberadaan akuifer air tanah diduga berada. Pada kedalaman di bawah $35 \mathrm{~m}$, nilai resisivitas cenderungan meningkat dan terus meningkat sampai kedalaman dibawah 40 m (Gambar 11).

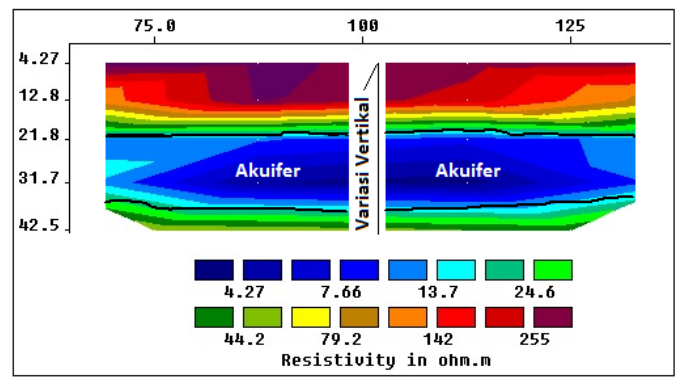

\section{Gambar 11. Variasi vertikal di lintasan 3}

Dari beberapa lapisan isoresistivity tersebut terlihat bahwa lapisan yang banyak mengandung air tanah berada pada kedalaman $21-40 \mathrm{~m}$. Sumur bor dapat dibuat di lokasi ini dengan kedalaman hingga $45 \mathrm{~m}$ (Paling potensial berada pada titik dengan Koordinat $2^{\circ} 55^{\prime} 34.44^{\prime \prime} \mathrm{S}$ dan $32^{\circ} 45^{\prime} 56.02 " \mathrm{E}$ ) dan air diperkirakan dijumpai mulia kedalaman $20 \mathrm{~m}$ (Gambar 12).

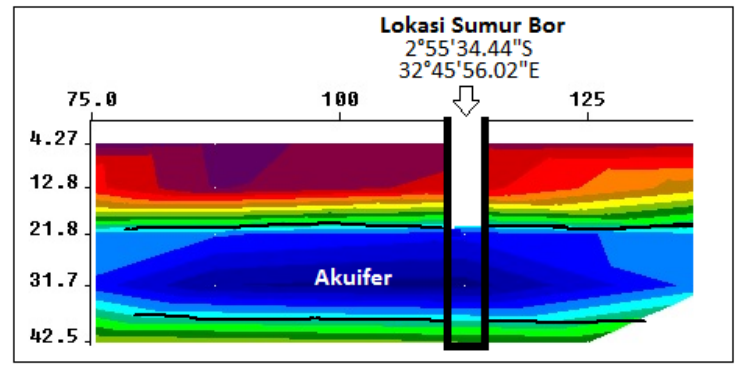

Gambar 12. Lokasi Rekomendasi Sumur Bor di Kampung Waremu

\subsection{Kampung Bisa}

Lokasi survei terletak pada $02^{0} 43^{\prime} 04.65^{\prime \prime S}$ dan $132^{0} 07^{\prime}$ 41.39"E , berada di Kampung Bisa, Distrik Teluk Patipi, Kabupaten Fak-Fak. Lokasi ini berada pada ketinggian $\pm 35 \mathrm{~m}$ diatas permukaan air laut dan berjarak $\pm 300 \mathrm{~m}$ dari garis pantai. Panjang bentangan $200 \mathrm{~m}$, dengan spasi elektroda $25 \mathrm{~m}$ dan arah lintasan relatif Barat - Timur $\left(\mathrm{N} 90^{\circ} \mathrm{E}\right)$. Hasil yang diperoleh dari pengolahan data dengan mengunakan sofware Res2Dinv dapat diklasifikasikan menjadi beberapa lapisan isoresistivity (batuan dengan tahanan jenis sama) dengan kesalahan RMS $19.7 \%$, seperti terlihat pada Gambar 13. 


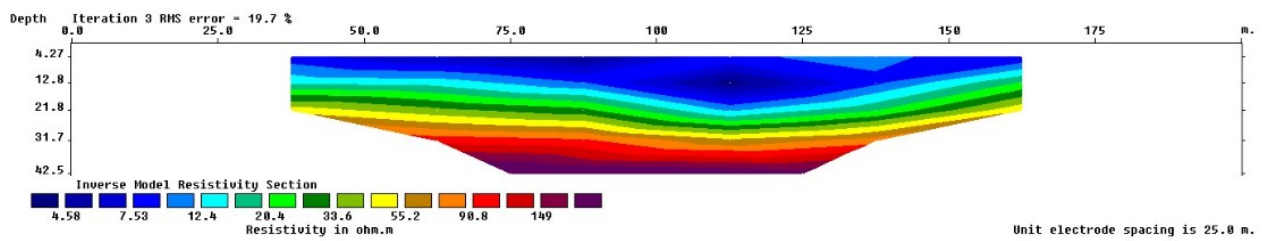

Gambar 13. Hasil pengolahan data resistivity dengan menggunakan Res2Dinv di Kampung Bisa, Distrik Teluk Patipi, Kabupaten Fak-Fak.

Nilai tahanan jenis kearah lateral/horisontal tidak mengalami variasi/perbedaan yang signifikan. Nilai tanahan jenis yang lebih tinggi berada di bagian bawah (Warna Cokelat), sedangkan nilai tahanan jenis rendah berada di bagian atas. Nilai tahanan jenis pada kedalaman $0-20$ (bagian atas) berkisar antara $5-20 \Omega \mathrm{m}$ (warna biru-hijau), sedangkan pada kedalaman $20-42 \mathrm{~m}$ didominasi oleh nilai tahanan jenis yang lebih rendah, yakni antara $50-150 \Omega \mathrm{m}$ (warna kuning - cokelat).

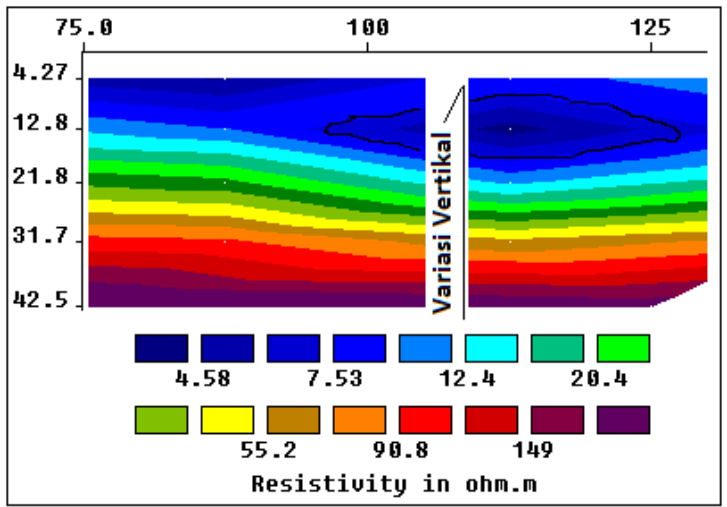

Gambar 14. Variasi vertikal di lintasan 4

Pada arah vertikal, nilai tahanan jenis mengalami variasi/perbedaan yang mencolok. Pada bagian atas (kedalaman 0-18 m) nilai tahanan jenis dibawah $10 \Omega \mathrm{m}$ dan terendah 5 $\Omega \mathrm{m}$ dijumpai pada jarak $115 \mathrm{~m}$ dari titik awal geolistrik pada kedalaman $15 \mathrm{~m}$. Lapisan ini diduga merupakan lapisan batuan yang banyak menyimpan air. Resistivitas mengalami peningkatan menjadi $12-30 \Omega \mathrm{m}$ pada kedalaman 21 - 35 m (warna kuning - hijau), dan terus mengalami peningkatan pada kedalaman 35 - $40 \mathrm{~m}$, dimana nilai resistivitas mencapai $150 \Omega \mathrm{m}$ (Gambar 4).

Dari beberapa lapisan isoresistivity tersebut terlihat bahwa lapisan yang banyak mengandung air tanah berada pada kedalaman 10 - $20 \mathrm{~m}$ dan pada jarak $115 \mathrm{~m}$ dari titik awal bentangan. Sumur bor dapat dibuat di lokasi ini dengan kedalaman hingga $30 \mathrm{~m}$ (Paling potensial berada pada titik dengan Koordinat $2^{\circ} 43^{\prime} 04.28^{\prime \prime} \mathrm{S}$ dan $132^{\circ} 07^{\prime} 40.09^{\prime \prime E}$ ) dan air diperkirakan dijumpai mulai kedalaman $10 \mathrm{~m}$ (Gambar 15)

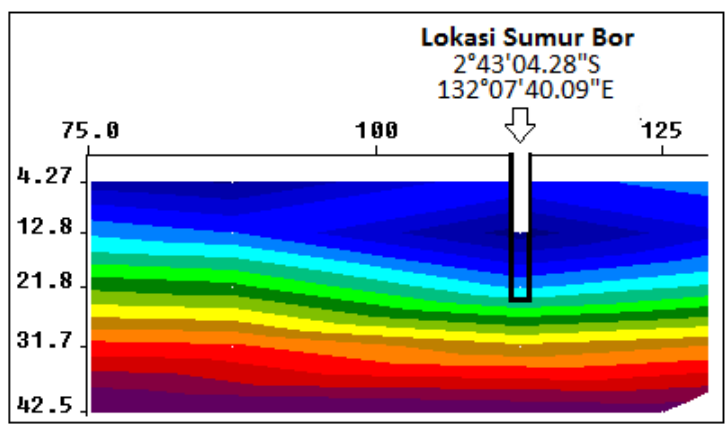

Gambar 15. Lokasi Rekomendasi Sumur Bor di Kampung Bisa

\section{Kesimpulan}

Dari hasil survei metode geolistri sounding di beberapa kampung di Kabupaten Fak Fak, maka diperoleh kesimpulan :

1. Untuk Kampung Bahamdandara, lapisan yang banyak mengandung air tanah berada pada kedalaman 15 - $30 \mathrm{~m}$ (Koordinat $2^{\circ} 49^{\prime}$ 59.77" S dan $132^{\circ} 41^{\prime} 23.33 "$ E). Sumur bor dapat dibuat dengan kedalaman hingga $40 \mathrm{~m}$ dan air diperkirakan dijumpai mulia kedalaman $12 \mathrm{~m}$.

2. Untuk Kampung Woos, lapisan yang banyak mengandung air tanah berada pada 
kedalaman 8 - 25 m (Koordinat $2^{\circ} 54^{\prime} 19.84^{\prime \prime}$ $\mathrm{S}$ dan $\left.132^{\circ} 44^{\prime} 46.01^{\prime \prime}\right)$. Sumur bor dapat dibuat sampai dengan kedalaman 40 m Edan air diperkirakan dijumpai mulia kedalaman 8 $\mathrm{m}$.

3. Untuk Kampung Waremu, lapisan yang banyak mengandung air tanah berada pada kedalaman $21-40 \mathrm{~m}$ (Koordinat $2^{\circ} 55^{\prime} 34.44^{\prime \prime} S$ dan $32^{\circ} 45^{\prime} 56.02^{\prime \prime E}$ ). Sumur bor dapat dibuat hingga kedalaman $45 \mathrm{~m}$ dan air diperkirakan dijumpai mulia kedalaman 20 $\mathrm{m}$.

4. Untuk Kampung Bisa, lapisan yang banyak mengandung air tanah berada pada kedalaman $10-20 \mathrm{~m}$ (Koordinat $2^{\circ} 43^{\prime} 04.28^{\prime \prime} S$ dan $\left.132^{\circ} 07^{\prime} 40.09 " E\right)$. Sumur bor dapat dibuat hingga kedalaman $30 \mathrm{~m}$ dan air diperkirakan dijumpai mulai kedalaman $10 \mathrm{~m}$.

\section{DAFTAR PUSTAKA}

Grant, F, S., and West, G, F., 1965. Interpretation theory in applied geophysics :Mc-Graw-Hill Book Company.

Schon, J, H., 1996. Physical Properties of Rock : Fundamentals and Priciples of Petrophysics: Institute of Applied Geophysics, Austria

Telford, W.M. Geldart, L.P. Sheriff, R.E. Keys, D.A. (1974). Applied Geophysics. Cambridge University Press. Cambridge

Todd, 1980. Ground Water Hydrokoi. Second Edition, Jhon wiley \& Sons. New york http://psg.bgl.esdm.go.id 